\title{
Recombinant Vaccinia-TRP1
}

National Cancer Institute

\section{Source}

National Cancer Institute. Recombinant Vaccinia-TRP1. NCI Thesaurus. Code C29564.

A recombinant vaccinia virus encoding the melanocyte differentiation antigen tyrosinaserelated protein-1 (TRP-1) with potential use in cancer immunotherapy. ( $\mathrm{NCl04)}$ 